\title{
An Online Interaction Experience within Distance Education: A Course Design Proposal for the Basic Design Course of the Department of Architecture
}

\author{
Ümit Bayırıı ${ }^{1}$ (D), Enes Can Kılıç
}

${ }^{1}$ Pamukkale University, Faculty of Architecture and Design, Department of Industrial Design, Denizli

${ }^{2}$ Pamukkale University, Faculty of Architecture and Design, Department of Interior Architecture, Denizli

Geliş Tarihi / Received Date: 15.03.2021 Kabul Tarihi / Accepted Date: 06.09.2021

\begin{abstract}
Due to the COVID-19 outbreak, which was declared as a pandemic in 2020 by the World Health Organization, many educational institutions around the world started distance education. However, since distance education is an unusual field for the stakeholders of education, this sudden change created a chaos both for institutions in terms of providing the necessary infrastructure and for educators in terms of redesigning instruction techniques and tools. In this article, it is aimed to discuss a distance education course design proposal for basic design course, which is taught generally in the first two semesters within a studio environment at the department of architecture, through a) student opinions that were obtained through an online questionnaire that were conducted at the end of the semester, evaluations made by the authors about b) the process outputs and achievements and c) the tools. The results show that, the distance education course design proposal for the basic design course of the department of architecture, which requires collaboration and interaction between students and instructors, evaluated as being efficient both in terms of the tools and methods used and in terms of creating an online collaborative workspace.
\end{abstract}

Keywords: distance education, architecture education, basic design, collaboration, interaction

\section{Uzaktan Eğitimde Çevrimiçi Bir Etkileşim Deneyimi: Mimarlık Bölümü Temel Tasarım Dersi için Bir Ders Tasarımı Önerisi}

Özet

Dünya Sağlık Örgütü tarafından 2020 yılında pandemi olarak ilan edilen COVID-19 salgını nedeni ile, dünya genelinde birçok eğitim-öğretim kurumunda uzaktan eğitime geçilmiştir. Ancak, uzaktan eğitim, eğitimin tüm paydaşları için alışılmadık bir alan olduğu için, bu ani değişim hem gerekli altyapıyı sağlamak durumunda olan kurumlar hem de eğitim modellerini ve araçlarını güncellemek zorunda kalan eğitmenler için bir kaos ortamı yaratmıştır. Bu makalede; mimarlık bölümlerinde, genelde ilk iki yarıyılda, stüdyo ortamında uygulamalı olarak verilen temel tasarım dersini uzaktan eğitime adapte edebilmek için yeniden yapılandırılan bir ders tasarımı önerisini a) dönem sonunda gerçekleştirilen bir çevrimiçi anket ile elde edilen öğrenci görüşleri ve yazarların b) süreç çıktılarını, öğrenci kazanımlarını ve c) kullanılan araçları değerlendirmeleri üzerinden tartışmaya açmak amaçlanmaktadır. Süreç değerlendirildiğinde; öğrenciler ve eğitmenler arasında ortak çalışma ve etkileşim gerektiren mimarlık bölümü temel tasarım dersi için bir uzaktan eğitim modeli olarak önerilen bu ders tasarımının; gerek kullanılan araç ve yöntemler açısından gerek çevrimiçi ortak çalışma alanları yaratması bakımından verimli olduğu sonucuna varılmıştır.

Anahtar Kelimeler: uzaktan eğitim, mimarlık eğitimi, temel tasarım, işbirliği, etkileşim 


\section{Introduction}

The field of education is one of the most affected fields due to the COVID-19 outbreak. Most of the higher, secondary and primary education institutions all around the world were closed and converted their learning environment into an online modality (Bernardo \& Duarte, 2020; Gökbulut, 2021). Although people are on intimate terms with technology in the modern era, the sudden conversion from face-to-face education to distance education have caused adaptation problems for both educators and students. Despite the experienced problems, it was seen by the new acknowledgers that the distance education also has many advantages such as being flexible in terms of time and space, being easy in accessing online services and being cheap in terms of learning materials (Bates, 2015; Guri-Rosenblit, 2005; Hammad et al., 2018; Simonson et al., 2011).

Architectural and design education was also affected by the COVID-19 pandemic. Being a department that has crucial applied courses such as design studios, where experimentation, learning by doing, criticism, physical contact to the projects, collaboration and interaction between students and instructors are mandatory (Attoe \& Mugerauer, 1991; Chiu, 2002; Kocadere \& Özgen, 2012; Kurt, 2009; Kvan \& Yunyan, 2005), leaving the physical environment and moving online was challenging for architectural and design education. Many educators in the departments of architecture and design have been trying different methods and tools to compensate the handicap of being away from the design studio. This study touches on this issue by presenting a tested course design and an online collaboration tool (Miro) for basic design education of the department of architecture. For this purpose, first, literature review about distance education, architectural education and basic design education that constitute the background of the course is presented. Later, the offered course design and the evaluations of the students regarding the course is presented.

\section{Distance Education: Advantages and Disadvantages}

Many schools were closed all around the world to reduce the physical contact and decelerate the spread of COVID-19 pandemic. According to a report shared by UNESCO, a total of 63 million teachers and 1.5 billion students were affected by the COVID-19 pandemic in terms of school closures (UNESCO, 2021). For the purpose of, sustaining the education, many institutions moved their teaching and learning environment into an online modality and started doing distance education.

Distance education can be described as an education system that is conducted within an online medium via technological hardware and software that separates the participants from each other in terms of space and time (Aydemir, 2018; Schlosser \& Simonson, 2009). In other words, it is an education system that gathers the shareholders of the teaching and learning environment, which are educators, students, books, whiteboards, etc., within an online platform (Bernardo \& Duarte, 2020; Gökbulut, 2021; Wang et al., 2010). In terms of its purposes, there is not a difference between distance education and face-to-face education or formal education: both aims to transfer knowledge and skills. However, in terms of their tools that necessitate having smart devices and internet connection, differentiates online education from face-to-face education (Clark \& Mayer, 2011).

The history of distance education dates back to the 1800's. It first started by using letters as the medium, then in 1920's radios and in 1960's televisions were used to transfer knowledge and skills (Bates, 2015; Moore \& Kearsley, 2005). Although it extends back a long time, distance education became widespread through the invention of computers and internet. Due to the outbreaking COVID19 pandemic, distance education has become more popular and many studies discussing its advantages and disadvantages emerged (Bernardo \& Duarte, 2020; Hammad et al., 2018; Mayer, 2019).

The main advantage of the distance education over face-to-face education is the flexibility of time and space. While face-to-face education is limited to people that are present at the time and space in which the course is occurring, distance education is available for those who want to attend the course at different time and space alternatives (Bates, 2015; Guri-Rosenblit, 2005; Hammad et al., 2018). This 
facility creates opportunities especially to the people who have problems in attending the classes on time due to their jobs (Gökbulut, 2021). Another advantage of the distance education over face-toface education is the possibilities it serves in terms of accessing information and teaching tools due to the online interactive media and services at our disposal (Arkorful \& Abaidoo, 2014; Hammad et al., 2018). Besides, being cheap compared to the face-to-face education that needs continuously updated learning materials such as textbooks is yet another advantage of distance education (Hammad et al., 2018).

On the other hand, there are several disadvantages of distance education compared to the face-toface education. Distance education limits the social interaction and creates personal learning environments (Bernardo \& Duarte, 2020) where only the students with higher motivation and independent learning skills could benefit (Bernardo \& Duarte, 2020; Hammad et al., 2018). Furthermore, even if the distance education is cheap compared to the face-to-face education in terms of learning materials, it needs a budget in terms of the equipment and technical issues needed such as computers, smart mobile devices and a stable internet infrastructure (Arkorful \& Abaidoo, 2014; Bernardo \& Duarte, 2020).

Mentioned disadvantages of distance education, especially those that are related with social interaction and personal learning environments are critical for the disciplines whose curriculums depend on applied courses. Being one of those disciplines, architectural education and its first and one of the most important applied courses, basic design course is the subject of this study.

\section{The Situation of Basic Design Course within Architectural Education}

Architectural and design education prepare students for their profession by bringing them requisite knowledge, abilities and skills and educating them to gain a critical thinking to be able to find innovative solutions to design problem(s) given (Farivarsadri, 2001). In this respect, design studios play a significant role for not only the architectural education but also other design-based disciplines by bringing students' knowledge and skills by doing, experimenting, and practicing for real-life design problems as a challenge (Afacan, 2012). There is an interactive and collaborative environment where students learn from their instructors and fellows (Gelernter, 1988; Güngör, 2005; Sausmarez, 1983). Together with other theoretical and applied courses in the curriculum, design studios prepare students to their professions (Farivarsadri, 2001; Goldschmidt \& Tatsa, 2005). Each studio covers a major part of the semester in terms of course hours and credits and their content and learning outcomes differ and become more profession specific gradually.

Among these studios, basic design course (or studio) is the first place where students meet with architecture or other design-based disciplines. In this course, it is aimed to develop creativity and problem-solving abilities, perception and design language of the students (Boucharenc, 2006; Denel, 1981; Kuloğlu \& Asasoğlu, 2010; Lang, 1998; Salama, 1995). In order to actualize these aims, many two and three-dimensional projects related with Gestalt theory, composition, design elements and principles, materials and structure are conducted (Akbulut, 2010; Girgin, 2019).

Composition constitutes the center of basic design projects. It is expected that students organize design elements according to Gestalt theory and design principles in order to achieve two or threedimensional compositions that have aesthetically pleasing relations, proportions, figures, forms, angles, transformations, etc. (Ali \& Liem, 2014). Mittler (1994) associates design elements with the words and design principles with the grammar of a language. Since it is necessary to learn the alphabet before producing words, and to learn the grammar rules before forming sentences, students should first learn design elements, design principles and compositional issues regarding the organization of the elements in order to develop design outcomes (Ching, 2007). This principle is similar among architecture and design-based disciplines. While an industrial designer should consider the elements and their organization while designing a product, a graphic designer should do the same while designing a two-dimensional work and likewise, an architect should consider the elements and forms and their relations while designing a building. 
Another important factor for design studios and basic design course is collaboration. Since nowadays, famous design and architectural projects are conducted by design teams and international collaboration, intercultural communication and collaborative design has become a critical topic for architecture and design-based departments (Schadewitz, 2009), design students should be accustomed to this system by conducting group work projects starting from the basic design course. In this way, they can share their experiences, resources, ideas and learn the necessary skills related with communication, task distribution and coordination, decision making and time management (Chiu, 2002).

In light of the obtained background about the distance education, architectural education and basic design education, a distance education course design for basic design course of the department of architecture considering design elements, design principles, composition and collaboration is proposed.

\section{A Basic Design Course Proposal for Distance Education}

In the mentioned department of architecture, basic design course is taught for 8 hours per week for 14 weeks by a teaching team consisting of 7 members. In pre-pandemic semesters, there were between 70 to 85 students enrolled to the course and the number has been increasing gradually. Therefore, a minimum number of 80 students was expected to the first distance education basic design course. In order to cope with the chaos that a crowd consist of nearly 90 people will create within an online platform and to create an effective teaching and learning environment, it was decided to divide the students and the teaching team into three groups and restructure the basic design course syllabus to adapt distance education. Each team would focus on different aspects of the basic design course and students would circulate through the designated teams in order to learn about materials, structure, design elements, design principles and composition.

As it was expected, 92 students enrolled to the course and they were divided by 30,30 and 32 to the teaching teams. One team consisting of three members focused on the issue of materials, one team consisting of two members focused on the issue of structure, and other team consisting of two members focused on the issues of design elements, design principles and composition. In the first week an introduction was conducted with all of the students via Microsoft Teams in order to inform them about the procedure of the semester. Later on, each team conducted their themes three times with different student groups for four weeks (a total of 12 weeks). Finally, in the last week, again a general discussion was conducted with all of the students in order to evaluate the semester (Table 1).

Table 1. Syllabus of the Course

\begin{tabular}{|c|c|c|c|c|}
\hline Weeks & Audience & $\begin{array}{c}\text { Team } 1 \text { (two } \\
\text { members) }\end{array}$ & $\begin{array}{c}\text { Team } 2 \text { (two } \\
\text { members) }\end{array}$ & $\begin{array}{c}\text { Team } 3 \text { (three } \\
\text { members) }\end{array}$ \\
\hline 1 & Common course & Introduction & Introduction & Introduction \\
\hline $\begin{array}{l}2 \\
3 \\
4 \\
5\end{array}$ & $\begin{array}{c}\text { Student Group } 1 \\
\text { (30 students) }\end{array}$ & $\begin{array}{c}\text { Design elements, } \\
\text { principles, and } \\
\text { composition }\end{array}$ & Structure & Materials \\
\hline $\begin{array}{l}6 \\
7 \\
8 \\
9\end{array}$ & $\begin{array}{c}\text { Student Group } 2 \\
\text { (30 students) }\end{array}$ & $\begin{array}{c}\text { Design elements, } \\
\text { principles, and } \\
\text { composition }\end{array}$ & Structure & Materials \\
\hline $\begin{array}{l}10 \\
11 \\
12 \\
13\end{array}$ & $\begin{array}{c}\text { Student Group } 3 \\
\text { (32 students) }\end{array}$ & $\begin{array}{c}\text { Design elements, } \\
\text { principles, and } \\
\text { composition }\end{array}$ & Structure & Materials \\
\hline 14 & Common course & Discussion & Discussion & Discussion \\
\hline
\end{tabular}


The proposed course design in this paper focuses on the theme that aims to teach design elements, design principles and composition. In order to establish the communication, a WhatsApp group with the students was created and Microsoft Teams for videoconferencing was used. Furthermore, in order to create a collaborative environment among the students and teaching team, Miro software was used. It is a web based interactive collaboration tool that also allows users to download the software to their mobile devices and desktops. Studies show that peer tutoring has a positive effect on the learning of the students (Ali et al., 2015; Schleyer et al., 2005). Therefore, we enabled students to make tutoring and make presentations to their fellows.

\section{$1^{\text {st }}$ Week}

It was expected from the students to prepare their projects and homework by making PowerPoint presentations. Therefore, within the first week of the course, presentation about how to prepare and present an effective presentation both in terms of visuality and manner of telling was made by the teaching team (Table 2). Some student works in order to emphasize right and wrong approaches regarding PowerPoint presentations and presentation boards was presented. Since the students will make lots of presentations throughout their educational and professional life in order to present their projects, it was believed believed that the required visual literacy and presentation techniques are very vital to be obtained from the beginning of their education and therefore, this session was included at the very beginning of the course.

Later 10 groups of three students were constituted by using an online draw tool and groups were asked to prepare presentations for the next week about design elements and principles (presented by three groups), gestalt (three groups), color (two groups), and architecture and design terminologies (two groups). In that way, it was aimed to make students get used to making presentations and learn the required basic design knowledge and terminology.

Table 2. Weekly Course Schedule

\begin{tabular}{lll}
\hline Week & Course Subject & Homework \\
\hline 1 & Presentation techniques & $\begin{array}{l}\text { Prepare presentations about design } \\
\text { elements and principles, gestalt, color, and } \\
\text { architecture and design terminologies }\end{array}$ \\
2 & $\begin{array}{l}\text { Assignment 1) Student presentations } \\
\text { presentations about design elements and } \\
\text { principles, gestalt, color, and architecture } \\
\text { and design terminologies and discussion of } \\
\text { the presented issues }\end{array}$ & Bring 10 façade photos of buildings \\
& $\begin{array}{l}\text { 1) Presentation regarding the usage of Miro. } \\
\text { 2) Geometric analysis of the buildings via } \\
\text { Miro }\end{array}$ & $\begin{array}{l}\text { Prepare presentations of the investigated } \\
\text { buildings in terms of design elements, } \\
\text { principles, color and geometric analysis }\end{array}$ \\
& $\begin{array}{l}\text { Assignment 2) Student presentations of the } \\
\text { investigated buildings in terms of design } \\
\text { elements, principles, color and geometric } \\
\text { analysis and discussion of the presented } \\
\text { issues }\end{array}$ & Online questionnaire \\
\end{tabular}

\section{$2^{\text {nd }}$ Week}

In the second week, groups made their presentations, and the teaching team criticized their presentations, gave feedback, and completed the missing parts of the presented issues (Figure 1). Later, 15 groups of two were constituted by using an online draw tool for the new project and asked groups to search and bring a minimum of 10 photos of buildings for the next week. Regarding this task, 
students were encouraged to search for photos that presents a façade of a building, and buildings having both straight and curved forms.

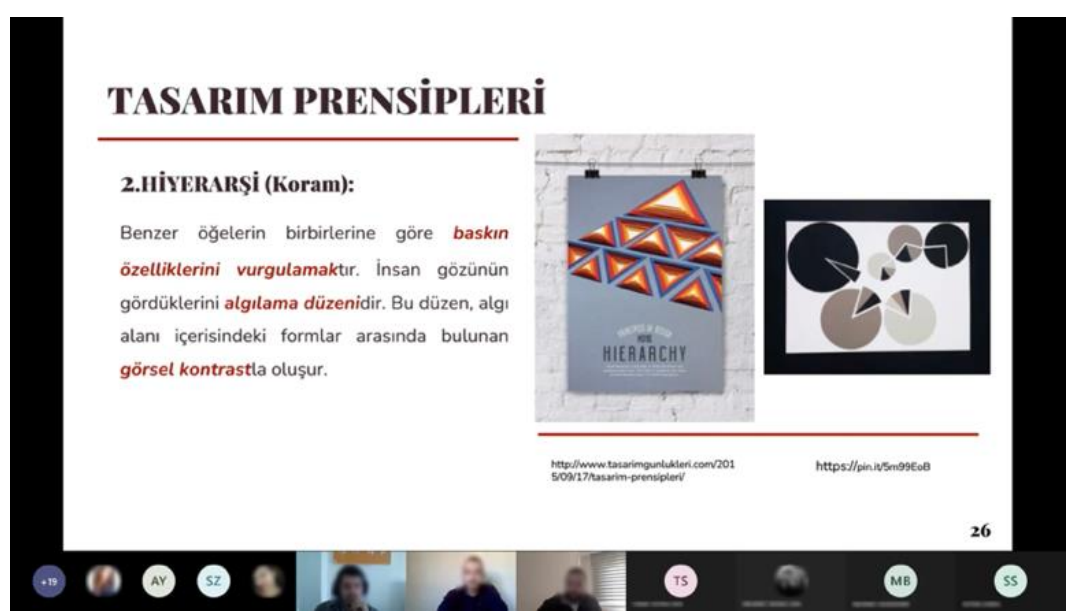

Figure 1. A Screenshot from One of the Presentations About Design Elements and Principles

\section{$3^{\text {rd }}$ Week}

For the $3^{\text {rd }}$ week, a template in the Miro was prepared and groups were asked to place the attained photos to the designated area before the course hour. Within the course, the findings were examined and the most suitable one for each group for the exercise on hand was chosen (Figure 2).

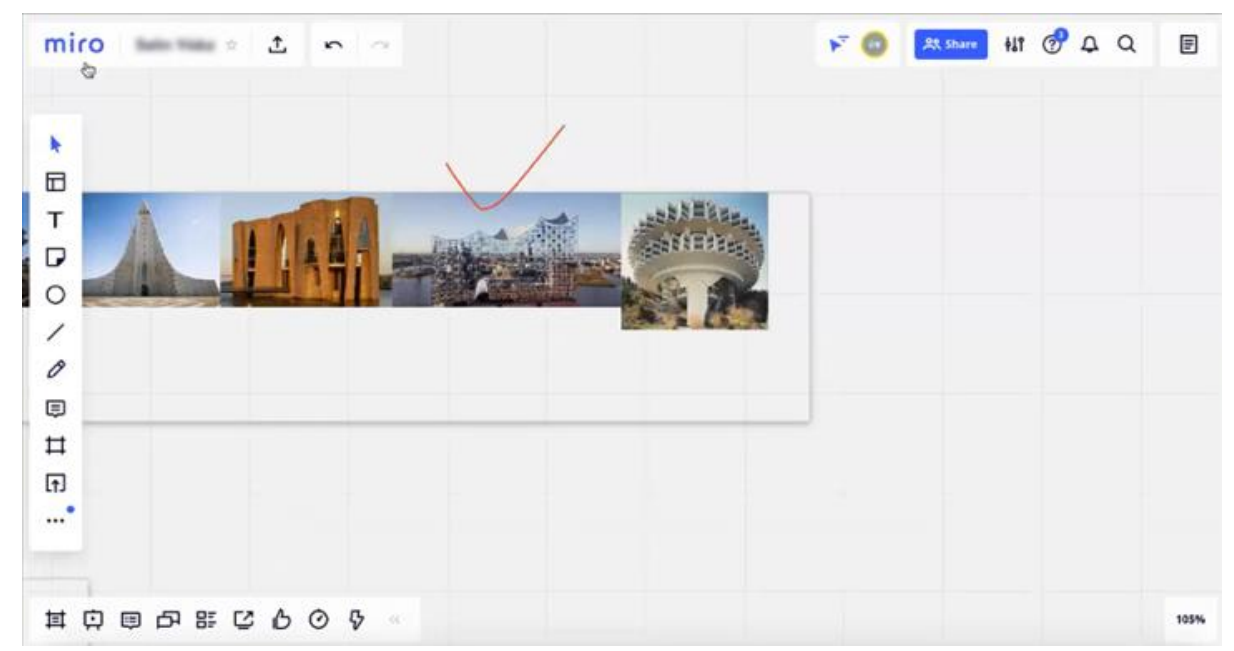

Figure 2. A Screenshot from the Building Selection Session of the Exercise

Later, a presentation regarding the usage of Miro and the procedure of the exercise was made by the teaching team. Within the project, students were asked to make a geometric analysis of the selected buildings by using Miro. Through this exercise, it was aimed to teach students that each building and structure is composed of geometrical shapes and relations, proportions, angles and transformations of these shapes. Through investigating the geometry and composition of existing buildings and obtaining a reverse engineering approach it was expected that students would start to look from the perspective of the architects and understand the design process.

For this exercise, Miro tool was found appropriate because it is easy to use, it allows for making drawings and taking notes, and most importantly, it allows for collaboration by enabling a synchronous working environment as if students are in the same room.

In the rest of the course, groups started to make geometric analysis of the selected buildings via Miro and teaching team gave them feedbacks (Figure 3). Finally, a presentation consisting of the 
investigation of the buildings in terms of design elements, principles, color and geometric analysis was given as a submission for the next and final week.

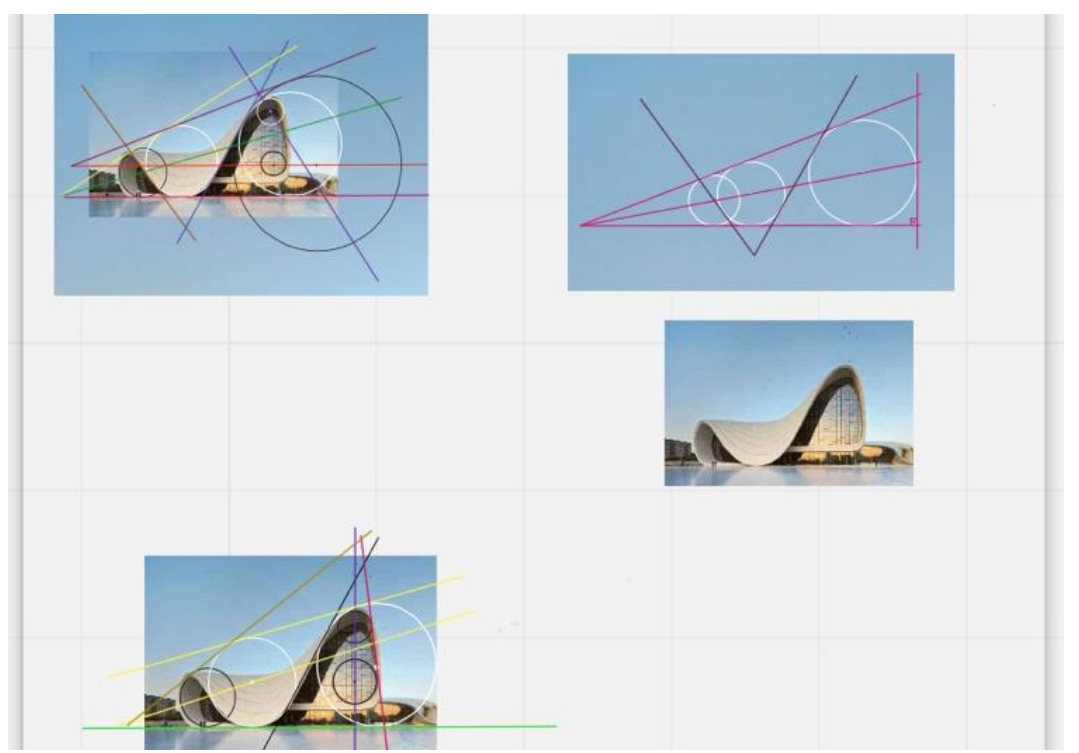

Figure 3. A Screenshot from the Geometric Analysis Exercise Feedback Session

\section{$4^{\text {th }}$ Week}

In the $4^{\text {th }}$ and final week of the course, groups made their presentations about determined buildings and teaching team gave them feedbacks to their findings in terms of design elements, design principles, color usage and geometric analysis (Figure 4). After the $4^{\text {th }}$ week, the same procedure was repeated twice with new student groups. At the end of the final course, all three student groups were delivered with an online survey and asked to respond anonymously in order to ensure objectivity.

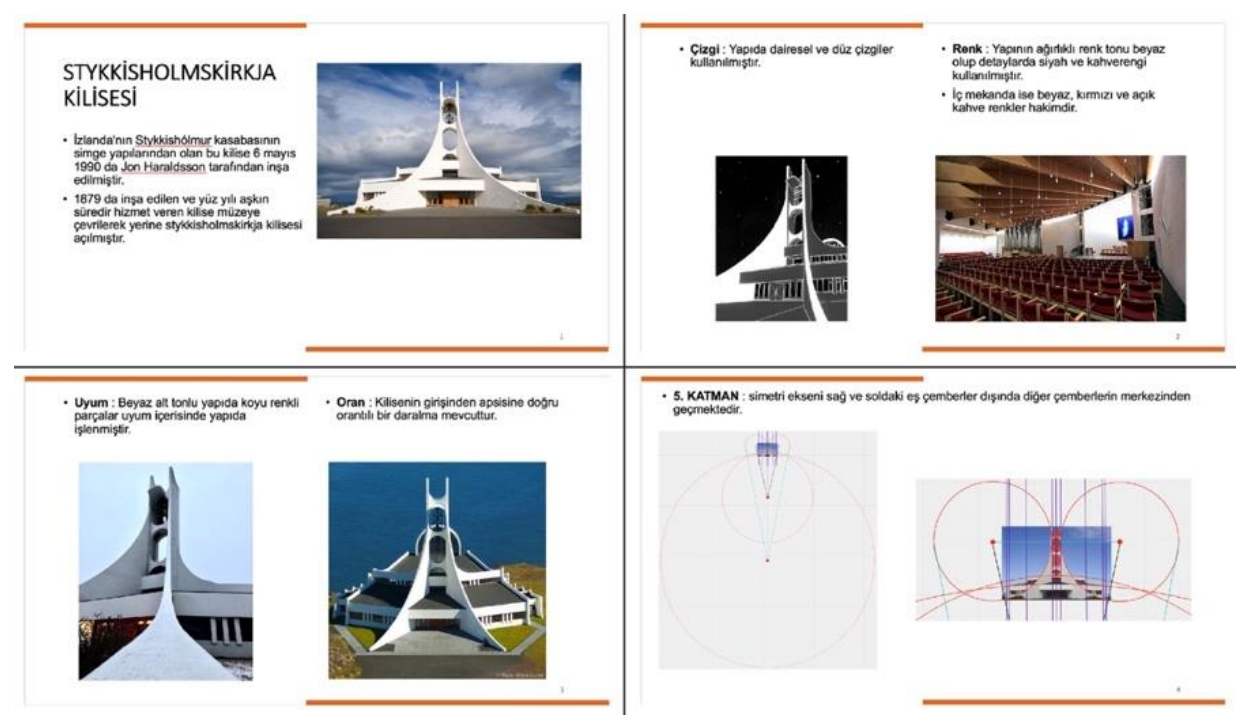

Figure 4. Screenshots from the Presentation of Stykkishólmskirkja Church

\section{The Evaluation of the Proposed Course Design Proposal}

The proposed basic design course proposal for distance education was evaluated through 1) student opinions obtained through an online questionnaire conducted at the end of the semester, evaluations made by the authors about 2 ) the process outputs and achievements and 3 ) the tools. 


\section{Evaluation of the Opinions of Students}

The student opinions were obtained by an online questionnaire containing eight open ended questions, which was prepared by getting expert opinions. The questions aimed to interrogate the encountered difficulties, the acquisitions and evaluations of the students regarding distance education and the followed course design together with teaching tools. The questionnaire got a total of 76 respondents within the 18-21 age range and with a participation of 47 females (62\%) and 29 males $(38 \%)$. The obtained data was analyzed through content analysis and thematic coding techniques. The determined themes were as follows: encountered problems related with technical issues, encountered problems related with the process, encountered problems related with communication, encountered problems related with health, evaluations related to the process, preferences, methods used to cope with the problems, evaluations related with the presentations, evaluations related with the geometric analysis and evaluations related with used tools.

The results show that, more than half of the students (57\%) did not have any difficulties due to distance education (Figure 5). However, $26 \%$ of the students had communication and process related issues such as division of labor because of not sharing the same environment physically. Some of the responds were as follows:

"Being unable to represent my gestures due to being distant caused communication problems".

"The process would take less time if we were face to face, deciding on division of labor and critical decisions were hard to manage due to distance".

Half of these students indicated that, they spent more time in order to overcome communication and process related issues. Furthermore, $15 \%$ of the students had problems related with technical issues such as problems related with poor internet connection and computer usage skills. Besides, $2 \%$ of the students declared that distance education caused them health problems related with eyes and back pain due to long hours of sitting in front of the computer. Moreover, $30 \%$ of the students indicated that, they would prefer face to face education to online education and $38 \%$ of them indicated the process was fluent, educational, effective and comprehensible.

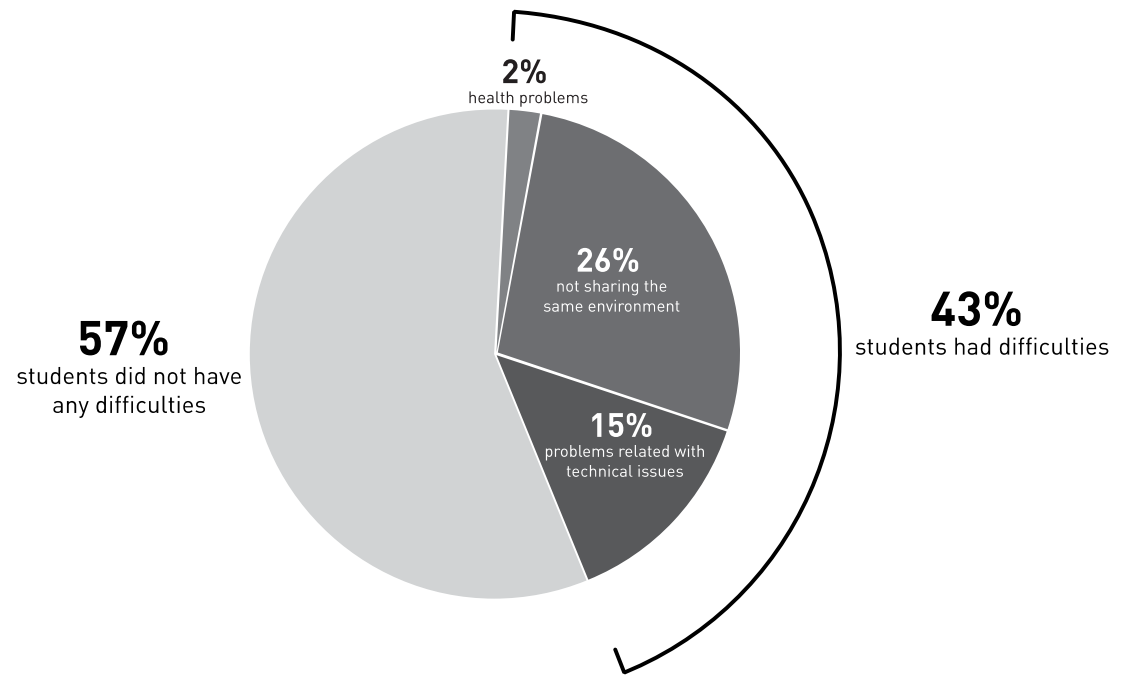

Figure 5. Difficulties Encountered Due to Distance Education

Another important finding was related with the followed course design. Regarding this topic, it was hard to dissociate which exercise cause which acquisition since the course was designed with a holistic approach and the contents are all related with each other. It was possible to see this approach in most the responds of the students as they indicated their acquisitions without distinguishing exercises. $41 \%$ of the students indicated that conducted exercises and the followed procedure helped them to look 
from a different perspective to their environments and buildings (Figure 6). Some of the responds were as follows:

"Learning about design elements and principles enabled us to look from a new perspective and making more accurate interpretations about structures. Learning about geometric analysis enabled us to see the hidden substructure of the buildings. In that way, we can see the starting points of a design process and understand that each element of a building has an aim".

"I learned to look from a critical perspective into buildings and elements. I can now imagine guidelines of a building when I look to it".

Furthermore, $14 \%$ of the students indicated that the course enhanced their observation ability and $11 \%$ of them indicated that learning about terms related with architecture and design had a positive effect on them. Some of the responds were as follows:

"Learning about architectural terms was helpful. When I hear those terms in other courses, I can now envision them. Furthermore, Gestalt draw my attention. Now, I look more carefully to billboards, advertisements, logos around me. Geometric analysis was also very useful. It brought me a new perspective. I started to draw imaginary lines and circles to buildings around me".

"Through learning about architectural terms, I started to observe buildings which I pass by without noticing before. I really felt that I study architecture".

Moreover, $10 \%$ of students declared that the course developed their presentation techniques and geometry related sense of aesthetic in terms of ratio, proportion and harmony. Besides, $6 \%$ of students indicated that the course enhanced their imagination skills.

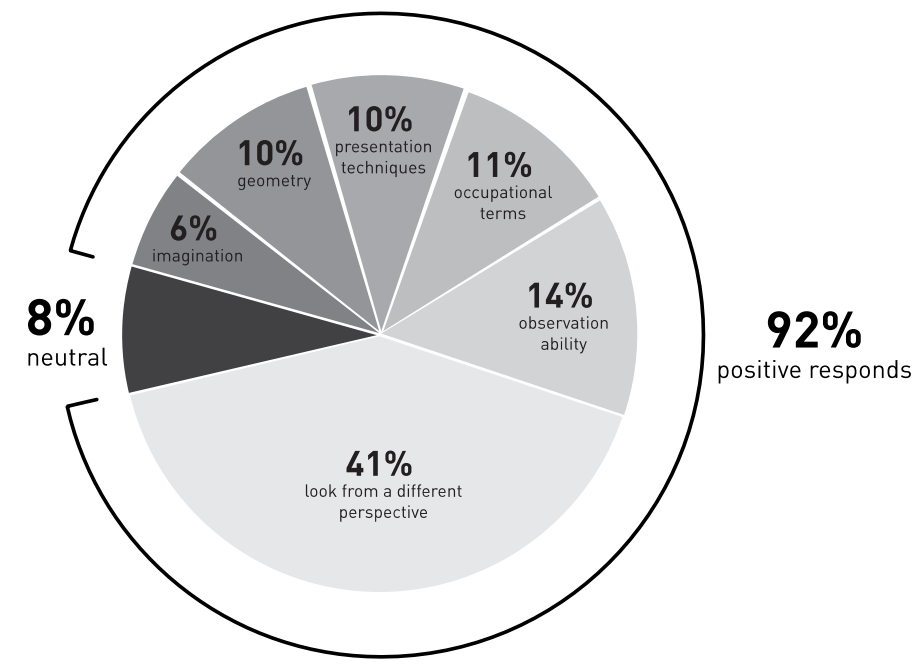

Figure 6. Responds of the Students Regarding the Followed Course Design

The final finding of the study was related with teaching tools. As part of the basic design course, Microsoft Teams and Miro were used. All of the participants evaluated Microsoft Teams as useful and practical. Furthermore, $90 \%$ of the students evaluated Miro as useful and practical in terms of working collaboratively. On the other hand, $10 \%$ of the students found it unpractical and hard to use. Some of the responds were as follows:

"Working and interacting with our fellows through Miro was a privilege. Besides, seeing what others are doing is very fruitful".

"Although our working environments are different, it is visible and accessible thanks to Miro. It creates a kind of online studio environment".

"I think it is unpractical. Being a person who are familiar with computers and this kind of software, I don't think it is easy to understand". 


\section{Evaluation of the Process Outputs and Achievements}

This section presents the evaluations made by the authors with regard to the obtained outputs within the process and the achievements of the students. Within the first assignment, groups made presentations related with design elements and principles, gestalt, color and architecture and design terminologies. The outputs of this assignment were evaluated in terms of 1 ) visual representation 2) rhetoric and 3) presented subjects.

In terms of the visual representation, most of the groups prepared well established and neat lay-outs (Figure 7a, 7b) considering the grid system, negative spaces and margins. However, some presentation pages have problems in terms of using a hard-to-read color (Figure 7c), using an eye-straining contrast regarding text and background (Figure 7a, 7d), using distorted images (Figure 7d), margins: positioning the elements too close to the outer boundaries (Figure 7c, 7e) and leaving little space between text and image (Figure 7e) and area usage: leaving meaningless empty spaces (Figure 7f).

In terms of the rhetoric, most of the groups made fluent presentations. Some groups became confused during the presentation. Since it was their first experience and the factor of excitement is considered, it can be evaluated as an understandable situation. However, some groups included too much text within a presentation page and preferred to read all of them instead of touching on the critical issues.

In terms of the presented subjects, all of the groups can be evaluated as successful since they covered the important issues, leaving minor details to instructors for expression.

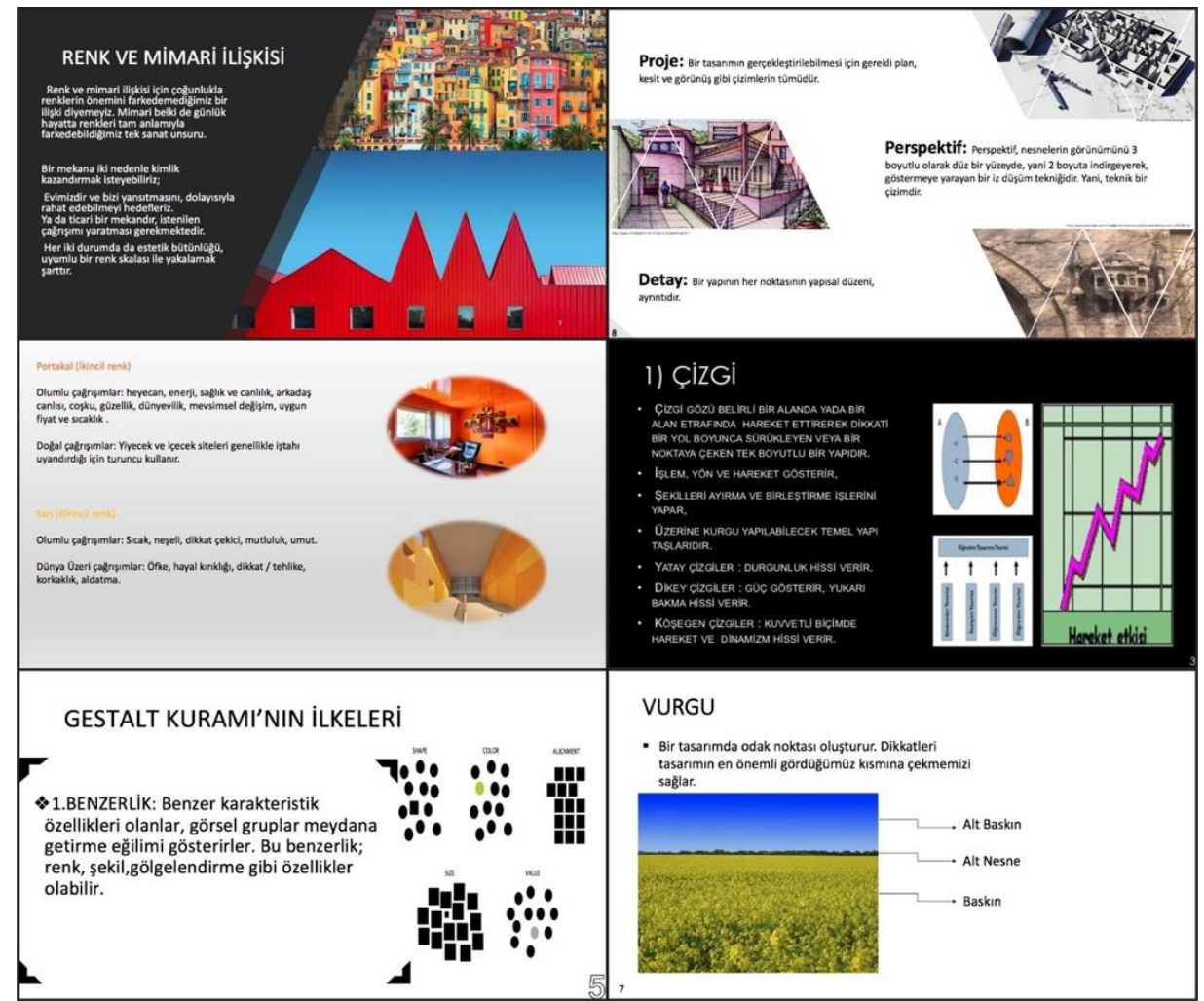

Top Row: $a$ and b, Middle Row: $c$ and $d$ and Bottom Row: $e$ and $f$

Figure 7. Presentation Examples of Assignment 1

Within the second assignment, groups made presentations of a building in terms of its design elements, principles, color, and geometric analysis. The presented buildings were as follows: Şeyh Zayed Bridge, Notre Dame, Sage Gateshead, Lotus Temple, Jubilee Church, Museum of Zhang Zhidong, Auditorio de Tenerife, Fennell Residence, Sydney Opera House, Heydar Aliyev Center, Pinhal Velho House, Riverside Museum, Elbphilharmonie, Palau de les Arts Reina Sofia, Ex of In House, China Maritime Museum, The House on the Flight of Birds, Casa Eliptica, Poly Grand Theatre, Hotel the 
Fontenay, Stykkishólmskirkja and Quadracci Pavilion. The outputs of this assignment were again evaluated in terms of 1) visual representation 2) rhetoric and 3) presented subjects.

In terms of the visual representation, it can be said that there was a clear improvement compared with the first assignment. Besides preparing presentations that have neat and visually coherent lay-outs and have less of the problems encountered in the first assignment, this time presentations started to have a visual appeal through the usage of a theme visually related with the context (Figure 8a), the usage of transparent backgrounds and elements having a visual balance (Figure $8 \mathrm{~b}$ ), the usage of appropriate images and placing them accordingly (Figure 8c) and the usage of minimalism (Figure 8d).

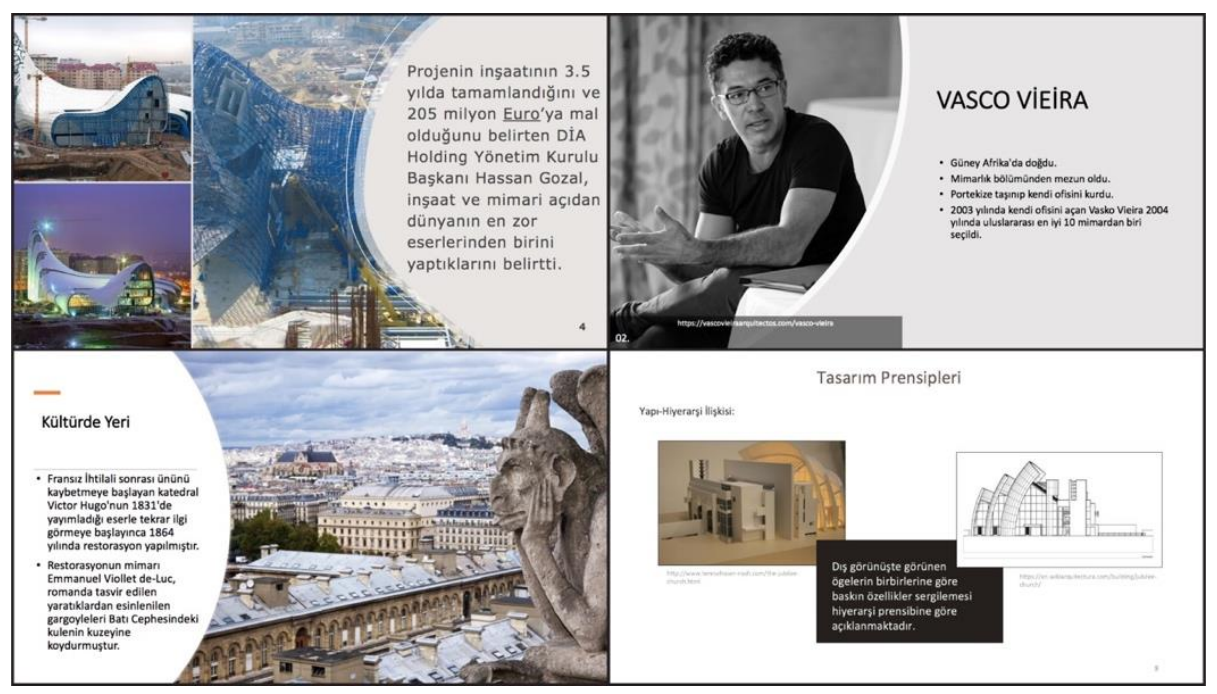

Top Row: $a$ and b, Bottom Row: $c$ and $d$

Figure 8. Presentation Examples of Assignment 2

In terms of the rhetoric, it is possible to say that each group improved themselves by preparing well, rehearsing, and conducting successful presentations in terms of rhetoric.

In terms of the presented subjects, all of the groups presented valuable information related with the building and the architect of it, together with the used design elements and principles and color. Furthermore, geometric analysis was the most laborious and the most important part of the assignment in terms of basic design issues especially composition. Regarding the geometric analysis, all of the groups investigated their buildings and tried to see the hidden geometrical shapes and their relations by working layer by layer (Figure 9). In these investigations, they made significant inferences regarding the usage of similar forms and their relations in terms of lay-out and golden ratio (Figure 10). 

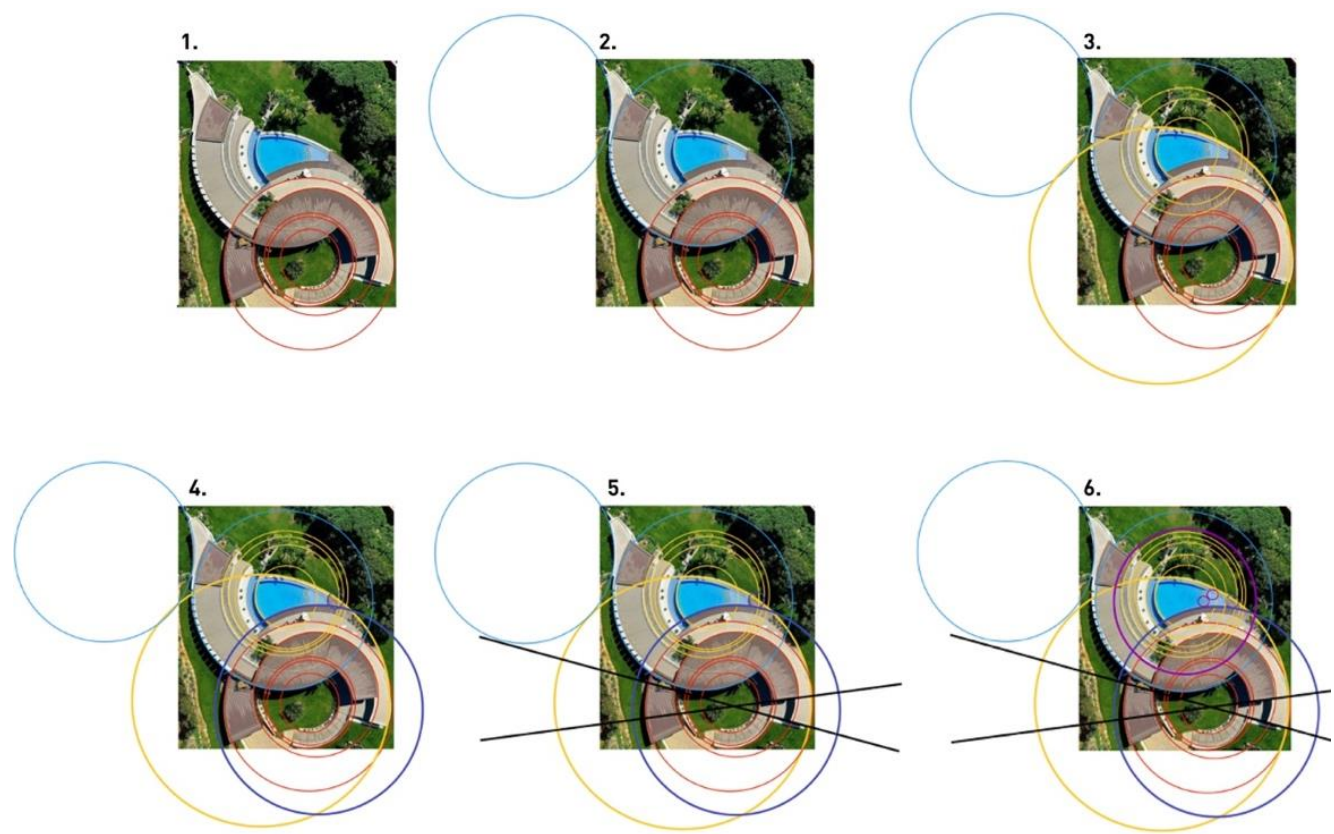

Figure 9. Geometric Analysis of Pinhal Velho House

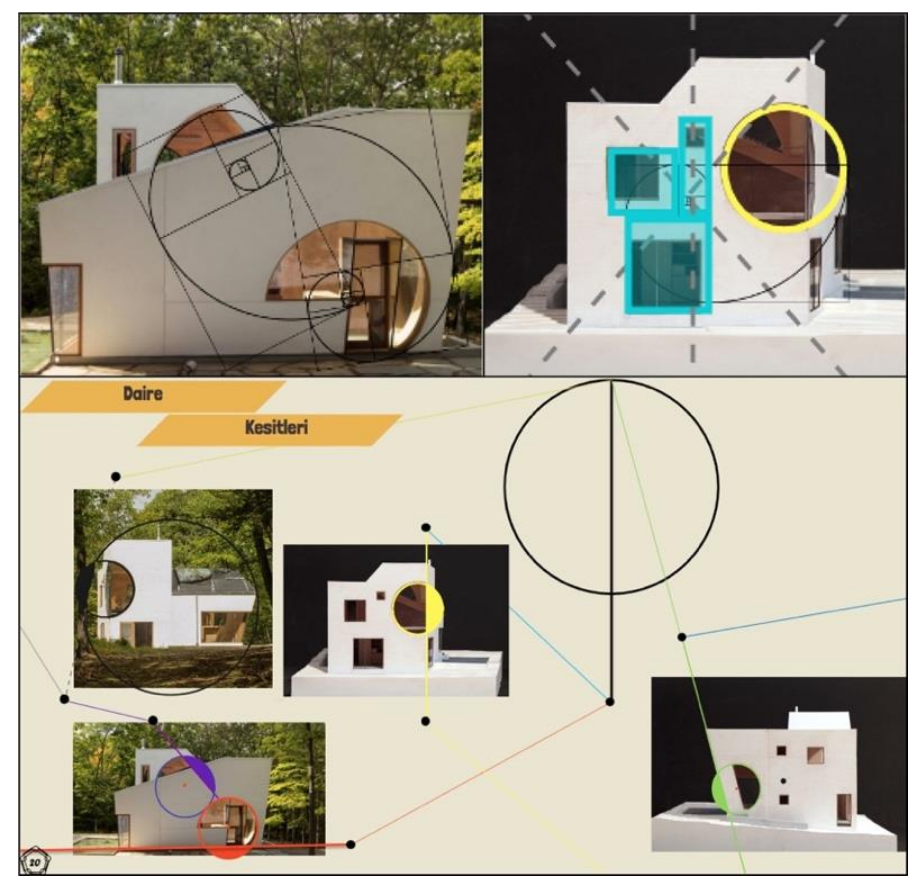

Figure 10. Geometric Analysis of Ex of In House

Through the completion of the course process and the assignments, the authors think that students gained a visual literacy and a design language in terms of interpreting and commenting about the environment around them. They also gained an understanding of design and see the logic behind the design process. Furthermore, the authors think that conducted assignments bring the students the critical points while making presentations both in terms of visual coherence and rhetoric. Besides, through the geometric analysis, they gain the importance of geometry and composition in architecture and the knowledge of how to use it within the design process. The results of the questionnaire are parallel with the thoughts of the authors therefore, the acquisitions of the course can be evaluated as effective for students. 


\section{Evaluations of the Used Tools}

Despite Microsoft Teams was also used throughout the course, the section concerns with the Miro and its potentials for the architecture and design education and professions. Miro can be evaluated as an empty wall that is located in online. People can simultaneously and in a synchronously write on it, draw on it, hang something on it and just like giving wall critiques in architecture and design education, people can stand and look what is on it (Figure 11). Furthermore, it has some advantages compared with the real-world situation of Miro which are whiteboards or walls.

First of all, it prevents the chaos that a large number of people would create being in the same physical environment and enables everybody to see the things clearly what is on board or wall without any obstacle. Furthermore, it is cheap and effortless. People do not need a pen, eraser, ruler or post-its. They can effortlessly draw a line, circle, square, etc. Besides, it has a bigger working area size that cannot be reached in a physical environment. Last but not least, it allows for the usage of several additional functions such as timer, voting tool, chat, templates, etc. The authors think that having these possibilities make Miro an efficient tool especially for brainstorming, planning and decision-making phases of a design process.

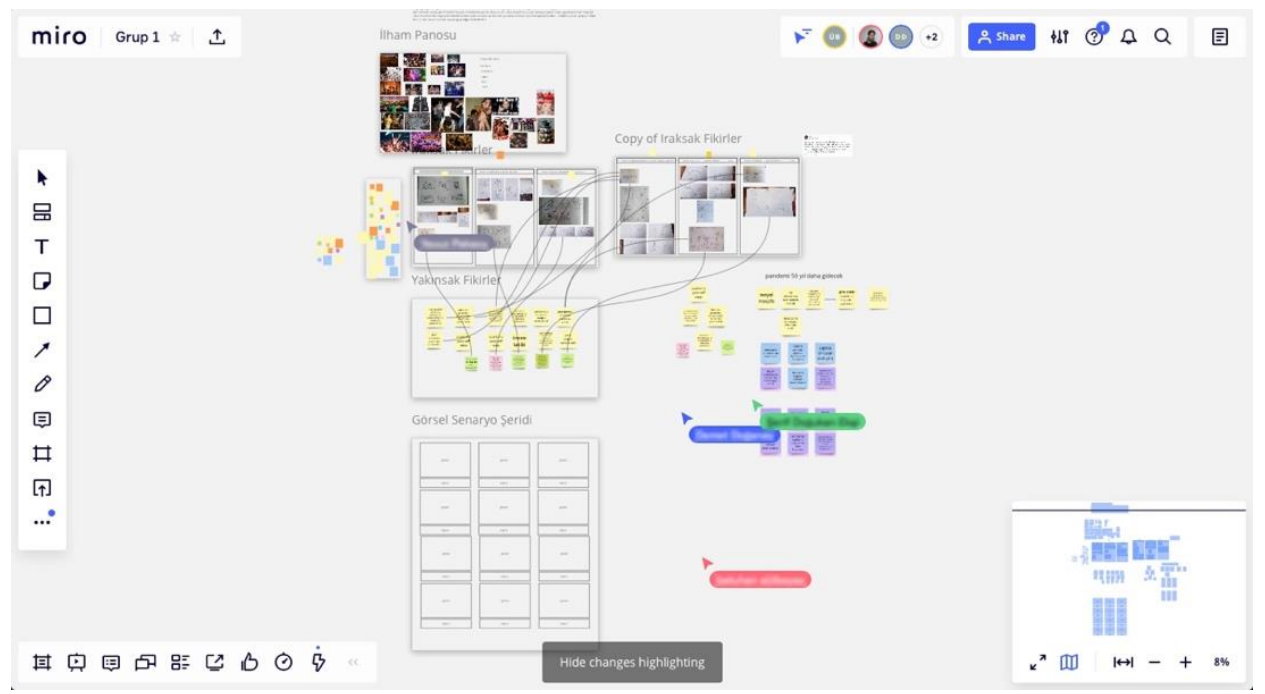

Figure 11. A Screenshot of a Miro Whiteboard Taken During a Workshop that is not in the Scope of This Paper

\section{Discussion and Conclusion}

COVID-19 outbreak has caused educational systems to move online all around the world in an unexpected way. This sudden change affected both students and educators, and also pedagogy and instruction techniques. Therefore, it is important to see how different institutions around the world approaches distant education and what solutions they offer. In that sense, this study proposes a distance education course design for basic design course of the department of architecture.

The results of this paper show similarities with the literature. Bates (2015), Guri-Rosenblit (2005) and Hammad et al. (2018) argued that distance education is superior to face-to-face education in terms of enabling the flexibility of time and space. This situation was in a parallel way within this study. Although the course was conducted simultaneously by the participation of all of the students at the same time, the flexibility of space prevented the chaos that would have happen with the participation of 90 students.

According to the literature, distance education requires some equipment such as computers, smart mobile devices and some technical issues such as a stable internet infrastructure and also a sophisticated computer usage skill (Arkorful \& Abaidoo, 2014; Bernardo \& Duarte, 2020). The results 
of this paper Show that $15 \%$ of the students indicated that they had problems related with poor internet connection and computer usage skills.

The biggest disadvantages of distance education compared with the face-to-face education was indicated as the lack of social interaction by Bernardo and Duarte (2020) and Misra and Misra (2013). $26 \%$ of the students participated to the study indicated that they had communication problems because of not sharing the same environment.

It is clear that distance education both have some advantages and disadvantages compared with the face-to-face education. In order to benefit for those advantages a restructured course design and appropriate teaching tools are necessary (Cheng, 2003). In terms of architecture education, in which communication, collaboration and interaction is crucial, facilitating appropriate instructional techniques and teaching tools for distance education become more of an issue. In this context, this paper discusses a distance education course design proposal together with an online collaboration tool for basic design course of the department of architecture. The proposed course design that adopts teaching presentation techniques, design elements, design principles, gestalt and composition through geometric analysis was evaluated as beneficial for students in terms of bringing a sense of visual and compositional literacy, an architectural and designer point of view and a reasoning of critical decisions given by architects in the design process. Furthermore, the used teaching tools, especially Miro, were evaluated as practical and useful in terms of working collaboratively by the students and the instructors. In that sense, both the proposed course design and the used tools can be evaluated as having a potential for the future distance education scenarios or a hybrid system that is a combination of both traditional in-class education and distance education.

It should be stated that, the findings of this study cannot be generalized. Conducting similar studies that present positive and negative sides of different approaches would be valuable during this period and in terms of preparing for potential forthcoming scenarios.

\section{Acknowledges}

This study was conducted in the basic design course at Pamukkale University Department of Architecture within the Fall semester of 2020-2021. We would like to thank to the other teaching members, Assoc. Prof Dr. Işıl Uçman Altınışık, Fazıl Akın, Dilek Avsan, Saniye Fışgın Korkmaz and Gökçe Erdemir. Furthermore, we would like to thank to all students who participated to our study.

\section{Author Contribution}

Both authors took part in preparing the experimental environment, following the experimental process, collecting data and performing statistical analyzes. The authors co-authored, read, and approved the article.

\section{Ethic}

There are no ethical issues with the publication of this article.

\section{Conflict of Interest}

The authors state that there is no conflict of interest.

\section{ORCID}

Ümit Bayırlı (D) https://orcid.org/0000-0001-7863-8563

Enes Can Kılıç iD https://orcid.org/0000-0003-3180-7643 


\section{References}

Afacan, Y. (2012). Investigating the effects of group working in studying interior architecture. Procedia Social and Behavioral Sciences, 51, 506-511. http://doi.org/10.1016/j.sbspro.2012.08.197

Akbulut, D. (2010). The effects of different student backgrounds in basic design education. Procedia Social and Behavioral Sciences, 2, 5331-5338. https://doi.org/10.1016/j.sbspro.2010.03.868

Ali, A., \& Liem, A. (2014). The use of formal aesthetic principles as a tool for design conceptualisation and detailing. Proceedings of NordDesign 2014, 490-499. https://www.designsociety.org/ publication/36293/The+use+of+Formal+Aesthetic+Principles+as+a+Tool+for+Design+Conceptual isation+and+Detailing

Ali, N., Anwer, M., \& Abbas, J. (2015). Impact of peer tutoring on learning of students. Journal for Studies in Management and Planning, 1(2), 61-66. https://files.eric.ed.gov/fulltext/ EJ1147960.pdf

Arkorful, V., \& Abaidoo, N. (2014). The role of e-learning, the advantages and disadvantages of its adoption in higher education. International Journal of Education and Research, 2(12), 397-410. https://www.ijern.com/journal/2014/December-2014/34.pdf

Attoe, W., \& Mugerauer, R. (1991). Excellent studio teaching in architecture. Studies in Higher Education, 16(1), 41-50. https://doi.org/10.1080/03075079112331383081

Aydemir, M. (2018). Uzaktan eğitim program, ders ve materyal tasarımı. Eğitim Yayınevi.

Bates, A. W. (2015). Teaching in a digital age. BC Campus.

Bernardo, N., \& Duarte, E. (2020). Design, education, and the online tech-pandemic. Strategic Design Research Journal, 13(3), 577-585. http://10.4013/sdrj.2020.133.22

Boucharenc, C. G. (2006). Research on basic design education: An international survey. International Journal of Technology and Design Education, 16, 1-30. http://10.1007/s10798-005-2110-8

Cheng, N. Y. (2003). Approaches to design collaboration research. Automation in Construction, 12(6), 715-723. http://10.1016/S0926-5805(03)00059-1

Ching, F. D. K. (2007). Architecture form, space, and order. John Wiley \& Sons.

Chiu, L. (2002). An organizational view of design communication in design collaboration. Design Studies, 23(2), 187-210. https://doi.org/10.1016/S0142-694X(01)00019-9

Clark, R. C., \& Mayer, R. E. (2011). E-learning and the science of instruction. Pfeiffer.

Denel, B. (1981). Temel tasarım ve yaratıcılık. Odtü Mimarlık Fakültesi Yayınları.

Farivarsadri, G. (2001). A Critical View on Pedagogical Dimension of Introductory Design in Architectural Education. CEBE Architectural Education Exchange 2001 Conference. http://citeseerx.ist.psu.edu/viewdoc/download?doi=10.1.1.548.2785\&rep=rep1\&type=pdf

Gelernter, M. (1988). Reconciling lectures and studios. Journal of Architectural Education, 41(2), 4652. https://doi.org/10.2307/1424834

Girgin, D. (2019). Öğretmenlerin tasarım odaklı düşünmeye ilişkin bilişsel yapıları ve kavramsal değişimleri. Journal of Ahi Evran University Social Sciences Institute, 5(2), 459-482. https://doi.org/10.31592/aeusbed.578729

Gökbulut, B. (2021). Uzaktan eğitim öğrencilerinin bakış açısıyla uzaktan eğitim ve mobil öğrenme. Eğitim Teknolojisi Kuram ve Uygulama, 11(1), 160-177. https://doi.org/10.17943/etku.797164

Goldschmidt, G., \& Tatsa, D. (2005). How good are good ideas? Correlates of design creativity. Design Studies, 26(6), 593-611. https://doi.org/10.1016/j.destud.2005.02.004 
Güngör, í. H. (2005). Temel tasar. Patates Baskı.

Guri-Rosenblit, S. (2005). 'Distance education' and 'e-learning': Not the same thing. Higher education, 49(4), 467-493. https://doi.org/10.1007/s10734-004-0040-0

Hammad, J., Hariadi, M., Purnomo, M. H., Jabari, N., \& Kurniawan, F. (2018). E-learning and adaptive e-learning review. IJCSNS International Journal of Computer Science and Network Security, 18(2), 48-55. http://paper.ijcsns.org/07_book/201802/20180207.pdf

Kocadere, S. A., \& Özgen, D. (2012). Assessment of basic design course in terms of constructivist learning theory. Procedia Social and Behavioral Sciences, 51, 115-119. https://doi.org/10.1016/j.sbspro.2012.08.128

Kuloğlu, N., \& Asasoğlu, A. O. (2010). Indirect expression as an approach to improving creativity in design education. Procedia Social and Behavioral Sciences, 9, 1674-1686. https://doi.org/10.1016/j.sbspro.2010.12.384

Kurt, S. (2009). An analytic study on the traditional studio environments and the use of the constructivist studio in the architectural design education. Procedia Social and Behavioral Sciences, 1, 401-408. https://doi.org/10.1016/j.sbspro.2009.01.072

Kvan, T., \& Yunyan, J. (2005). Students' learning styles and their correlation with performance in architectural design studio. Design Studies, 26(1), 19-34. https://doi.org/10.1016/ j.destud.2004.06.004

Lang, J. (1998). Öğrenciler için mimarlığa giriş: temel tasarım dersini yeniden düşünmek. In N. Teymur \& T. A. Dural (Eds.), Temel Tasarım/Temel Eğitim (pp. 3-13). Odtü Mimarlık Fakültesi Yayınları.

Mayer, R. E. (2019). Thirty years of research on online learning. Applied Cognitive Psychology, 33(2), 152-159. https://doi.org/10.1002/acp.3482

Mittler, A. G. (1994). Art in Focus. McGraw-Hill.

Moore, M. G., \& Kearsley, G. (2005). Distance education: A systems view of online learning. Cengage Learning.

Salama, A. (1995). New trends in architectural education: Designing the design studio. Tailored Text \& Unlimited Potential Publishing.

Sausmarez, M. D. (1983). Basic design: The dynamics of visual form. Van Nostrand Reinhold.

Schadewitz, N. (2009). Design patterns for cross-cultural collaboration. International Journal of Design, 3(3), 37-53. http://www.ijdesign.org/index.php/IJDesign/article/view/276/273

Schleyer, G., Langdon, G. S., \& James, S. (2005). Peer tutoring in conceptual design. European Journal of Engineering Education, 30(2), 245-254. https://doi.org/10.1080/03043790500087084

Schlosser, A. L., \& Simonson, M. (2009). Distance education: Definition and glossary of terms. Information Age Publishing.

Simonson, M., Schlosser, C., \& Orellana, A. (2011). Distance education research: A review of the literature. Journal of Computing in Higher Education, 23(2-3), 124-142. https://doi.org/10.1007/s12528-011-9045-8

UNESCO, (2021). Teacher task force calls to support 63 million teachers touched by the COVID-19 crisis. Retrieved June 6, 2021 from https://en.unesco.org/news/teacher-task-force-calls-support-63million-teachers-touched-covid-19-crisis

Wang, M., Ran, W., Liao, J., \& Yang, S. J. H. (2010). A performance-oriented approach to e-learning in the workplace. Educational Technology \& Society, 13(4), 167-179. https://www.jstor.org/stable/ jeductechsoci.13.4.167 